\title{
EFFECT OF INTERACTION BETWEEN INERTIAL FORCE AND NORMAL / REVERSE FAULT DISPLACEMENT ON PC RAHMEN BRIDGE
}

\author{
TOMOHIRO NAKANO
}

Department of Civil Engineering, Tokai University, Japan

\begin{abstract}
This paper conducts the analytical investigation of the differences between a bridge response under only inertial force and, that under both fault displacement and inertial force. These analyses were conducted by using static analyses and dynamic analyses considering relative displacements under normal and reverse slip with various fault displacements. According to the analytical results, it can be concluded that the effect of inertial force tends to be less, when the fault displacement becomes large.

KEYWORDS: Normal Fault, Reverse Fault, Inertial Force, EPS Method \& PC Rahmen Bridge
\end{abstract}

Received: Jun 20, 2017; Accepted: Jul 14, 2017; Published: Jul 31, 2017; Paper Id.: IJCSEIERDAUG20174

\section{INTRODUCTION}

The seismic response of bridges during earthquakes is caused by its inertial force. Practically speaking, many earthquakes brought about severe damage to bridges and this damage was wreaked by large inertial forces. As bridges are top-heavy structures, earthquakes affect bridge structures especially.

In general, a bridge structure is supported by more than one support point. When these support points vibrate in the same way, we can consider that the bridge is affected by only inertial force. However, when the support points oscillate in different ways, we should consider the damage caused by the relative displacement between the support points.

Especially, fault movement taking place on the ground-surface, large relative displacement will generate and it will affect the damage of the bridge. As a matter of course, the relative displacement depends on the magnitude of the fault. It also can be seen that the degree of bridge damage, considering both effect of its inertial force and relative displacement is greater than that only considering effect of its inertial force.

However, the effect of the fault displacement to bridges damage isn't clarified easily. Therefore, it is quite important for seismic design to have the information of the dominant factor of bridge damage.

Therefore, the differences between 1- the bridge response, only considering inertial force and, 2- the bridge response considering both fault displacement and inertial force are taken in this study. These analyses were conducted by using static analyses and dynamic analyses considering relative displacements under normal and reverse slip, with various fault displacements.

\section{TARGET BRIDGE AND ITS FE MODEL}

To evaluate the effect of fault displacement and the coupling effect of relative displacement and inertial force, a PC rahmen bridge shown in Figure 1 is analyzed. The cross section of the mainspan and the side spans are 
shown in Figure 2 and the one of the pier in Figure 3.

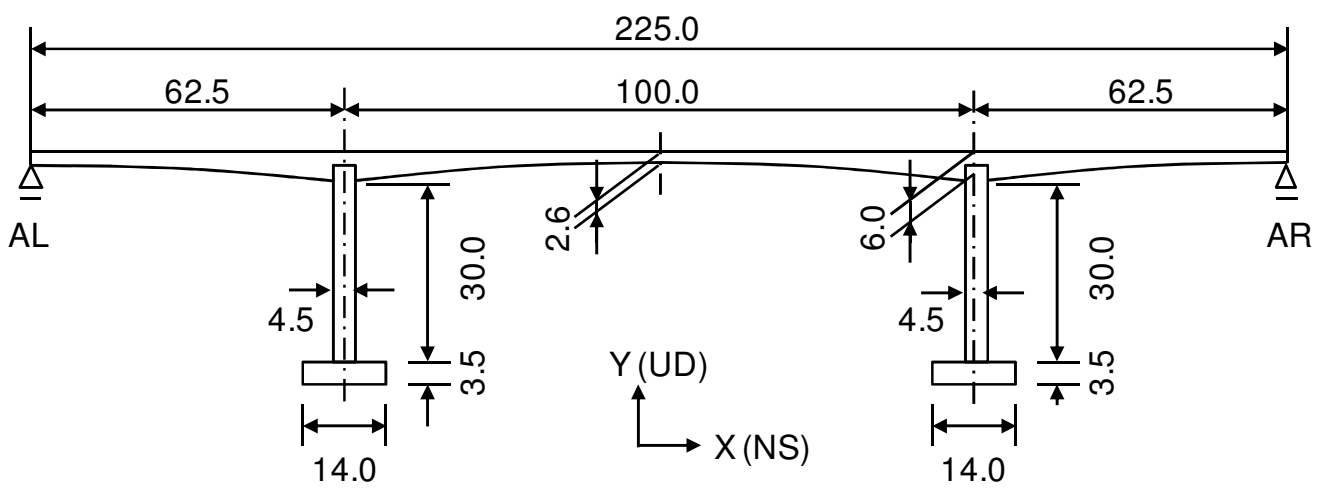

PL

PR

Figure 1: Target PC Rahmen Bridge

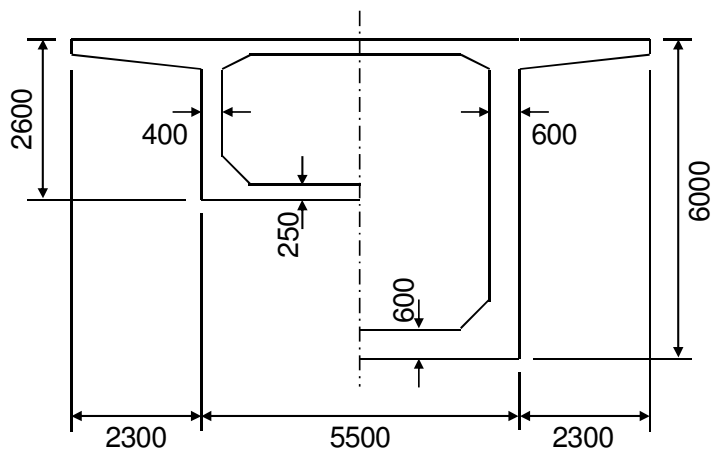

Figure 2: Cross Section of Main span and Side spans

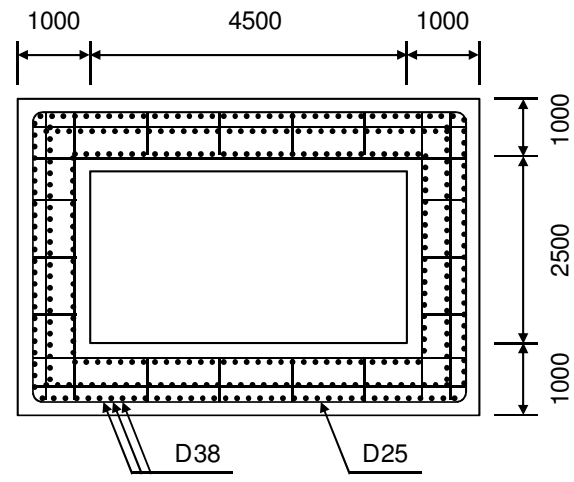

Figure 3: Cross Section of Pier

This bridge has the main span length of $100 \mathrm{~m}$ and, the each side span length of $62.5 \mathrm{~m}$. The pier height is $30 \mathrm{~m}$.

This bridge was idealized into 93 degrees of freedom lumped-mass system, and 92 non-linear beam elements were set as shown in Figure 4. The cross section of each member was divided into small cells to use the fiber model. In the model, nonlinear material models were applied to concrete, reinforcing bars and PCs. The constitutive relation proposed by Maekawa and Tsuchiya (2002) was used for each concrete cell (Figure 5) and the ones for reinforcing bars and PCs were the bilinear models. Material properties can be found in Table 1. 


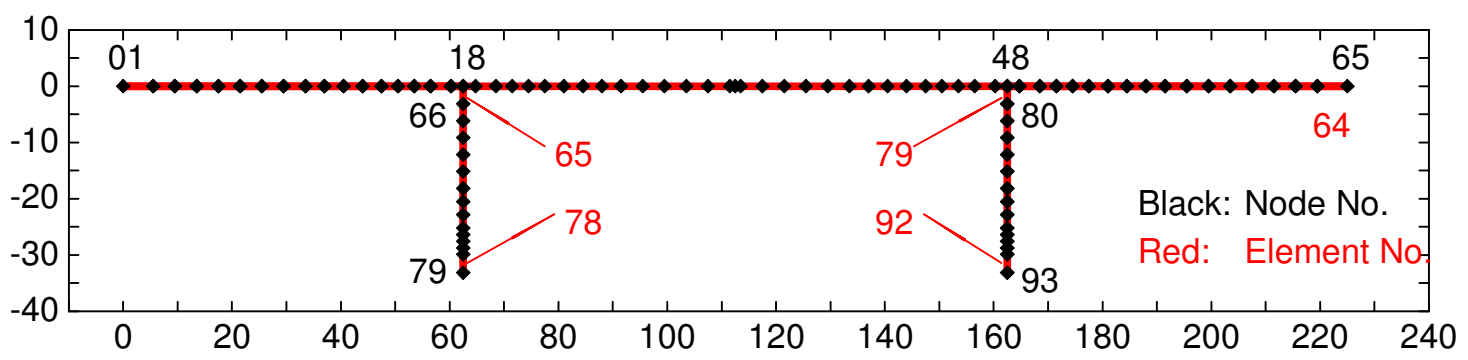

Figure 4: Beam Element Model

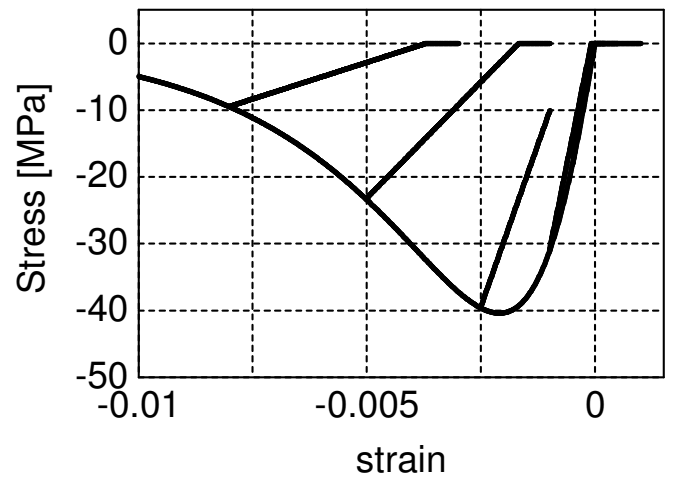

Figure 5: Constitutive Relation of Concrete

Table 1: Material Properties

\begin{tabular}{|c|c|c|}
\hline \multicolumn{3}{|c|}{ Concrete } \\
\hline \multirow{2}{*}{ Beam } & Design Strength & $f^{\prime}{ }_{c k}=40 \mathrm{MPa}$ \\
\cline { 2 - 3 } & Initial Elastic Modulus & $E_{c}=31 \mathrm{GPa}$ \\
\hline \multirow{2}{*}{ Pier } & Design Strength & $f^{\prime}{ }_{c k}=27 \mathrm{MPa}$ \\
\cline { 2 - 3 } & Initial Elastic Modulus & $E_{c}=26.5 \mathrm{GPa}$ \\
\hline \multicolumn{2}{|l|}{ Reinforcing Bar : SD345 } \\
\hline PC : 12S12.7 / SWPR7B \\
\hline
\end{tabular}

This bridge

Three specimens were prepared to observe the differences of travel time caused by the existence of foreign substance inside concrete, that is,

Slab A : stuffed concrete specimen

\section{Time-History of Ground Displacement from Acceleration Record by the EPS Method}

In this study, the seismic acceleration records observed in the 921 Chi-Chi earthquake in Taiwan were used. Though there are many observed acceleration records of the quake, this study applied NS and UD components of the acceleration records at TCU075 (Figure 6). 

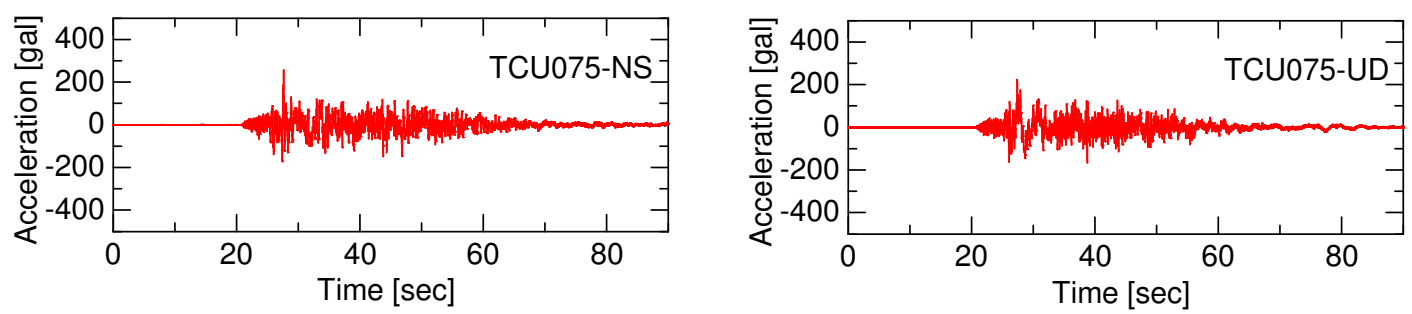

Figure 6: Ground Acceleration of 921 Chi-Chi Earthquakes at TCU075 in Taiwan (1999)

Using the EPS method, we can calculate time-history of ground displacement at TCU075 with various residual displacements. Table 2 shows the applied parameters of the EPSmethod. In the table, $\mathrm{t}_{1}$ indicates the time when we end the screening the erratic pattern of acceleration less than $\varepsilon_{1}$ [gal]. Also, $t_{2}$ indicates the time when we restart the screening the erratic pattern of acceleration less than $\varepsilon_{2}$ [gal]. That is, we omit the acceleration less than $\varepsilon_{1}$ [gal] during the period of $0<=\mathrm{t}<=\mathrm{t}_{1}$ and that less than $\varepsilon_{2}$ [gal] during the period of $\mathrm{t}_{2}<=\mathrm{t}<=\mathrm{t}_{\mathrm{f}}$ (end time of acceleration record).

Table 2: Parameters of EPS Method

\begin{tabular}{|c|c|c|c|c|}
\hline & $\mathbf{t}_{\mathbf{1}}$ [s] & $\boldsymbol{\varepsilon}_{\mathbf{1}}$ [gal] & $\mathbf{t}_{\mathbf{2}}$ [s] & $\boldsymbol{\varepsilon}_{\mathbf{2}}$ [gal] \\
\hline $\mathrm{NS}$ & 20.0 & 0.5 & $60.0-70.0$ & 5.0 \\
\hline $\mathrm{UD}$ & 20.0 & 2.0 & $60.0-70.0$ & 20.0 \\
\hline
\end{tabular}

Table 3 shows the residual displacements obtained by the EPS method using various $\mathrm{t}_{2}$. Combining the residual displacement, we have various residual relative displacement of the bridge.

The combination of the residual displacement in this study can be found in Table 4. Using the combination, we can represent the normal and reverse slip of from 0.84 to $5.08[\mathrm{~m}]$ and we can evaluate the effect of interactions of acceleration and relative displacement.

Table 3: Residual Displacement of Converted TCU075

\begin{tabular}{|c|c|c|c|c|c|c|c|c|}
\hline \multirow{2}{*}{$\mathbf{t}_{\mathbf{2}}[\mathbf{s}]$} & \multicolumn{2}{|c|}{ Residual Disp. } & \multirow{2}{*}{$\mathbf{t}_{2}[\mathbf{s}]$} & \multicolumn{2}{c|}{ Residual Disp. } & \multirow{2}{*}{$\mathbf{t}_{\mathbf{2}}[\mathbf{s}]$} & \multicolumn{2}{|c|}{ Residual Disp. } \\
\cline { 2 - 3 } \cline { 8 - 9 } & $\mathbf{N S}$ & $\mathbf{U D}$ & & $\mathbf{N S}$ & $\mathbf{U D}$ & & $\mathbf{N S}$ & $\mathbf{U D}$ \\
\hline 60.0 & -4.744 & -0.565 & 63.5 & +1.191 & -0.866 & 67.0 & -0.264 & +0.467 \\
\hline 60.5 & -4.708 & +0.256 & 64.0 & +1.762 & -0.252 & 67.5 & -0.383 & +0.048 \\
\hline 61.0 & -2.428 & -0.269 & 64.5 & +0.247 & +0.324 & 68.0 & -0.876 & +0.051 \\
\hline 61.5 & -1.393 & -2.211 & 65.0 & -0.415 & +1.013 & 68.5 & -0.633 & -0.127 \\
\hline 62.0 & -0.346 & -0.869 & 65.5 & -1.701 & +1.612 & 69.0 & +0.799 & -0.631 \\
\hline 62.5 & +0.546 & -0.828 & 66.0 & -0.965 & +0.857 & 69.5 & +1.801 & -1.550 \\
\hline 63.0 & +0.868 & -1.412 & 66.5 & -0.115 & +0.315 & 70.0 & +1.208 & -2.184 \\
\hline
\end{tabular}

\section{ANALYSIS OF A BRIDGE UNDER BOTH RELATIVE DISPLACEMENT AND INERTIAL FORCE}

\section{Analytical Cases}

The dynamic responses under both inertial force and relative displacement can be calculated, by inputting the time-history displacement obtained in chapter 3 to AL/PL and AR/PR in Figure 1. For example, combining the input waves as shown in Figure 7, we have the reverse fault condition with fault angle of 46.4 [degrees] and with fault displacement of $5.08[\mathrm{~m}]$.

All the cases of the analyses can be found in Table 4. 


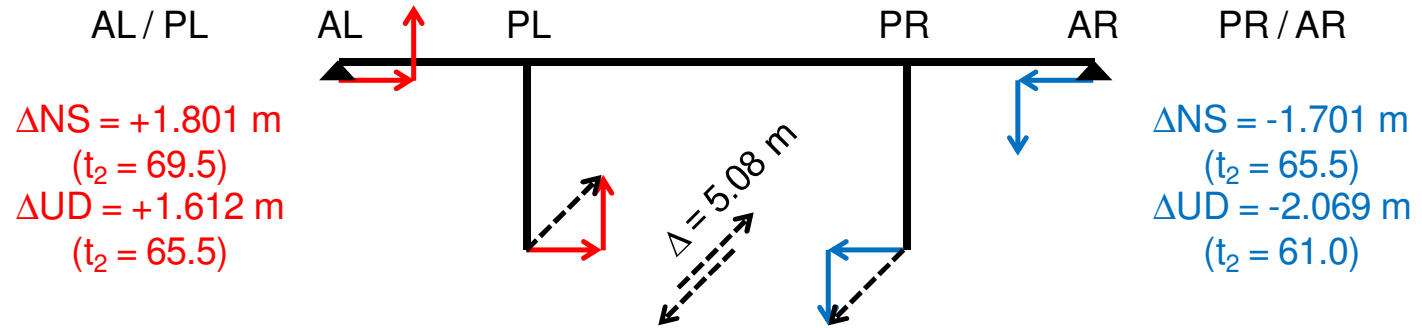

Figure 7: Relation of Combination of Input Displacement Waves and Fault Displacement

Table 4: Analytical Cases

\begin{tabular}{|c|c|c|c|c|c|}
\hline \multicolumn{3}{|c|}{ Normal Fault } & \multicolumn{3}{|c|}{ Reverse Fault } \\
\hline AL/PL & $\begin{array}{c}\text { Fault Disp. } \\
\text { and } \\
\text { Fault } \\
\text { Angle }\end{array}$ & PR/AR & AL/PL & $\begin{array}{r}\text { Fault Disp. } \\
\text { and } \\
\text { Fault } \\
\text { Angle }\end{array}$ & PR/AR \\
\hline $\begin{array}{c}\Delta \mathrm{X}=+1.208 \\
(\mathrm{t} 2=70.0 \mathrm{~s}) \\
\Delta \mathrm{Y}=+1.013 \\
(\mathrm{t} 2=65.0 \mathrm{~s})\end{array}$ & $\begin{array}{c}\text { NF084 } \\
\Delta=0.84 \mathrm{~m} \\
\phi=45.3\end{array}$ & \multirow{7}{*}{$\begin{array}{c}\Delta \mathrm{X}=+1.801 \\
(\mathrm{t} 2=69.5 \mathrm{~s}) \\
\Delta \mathrm{Y}=+1.612 \\
(\mathrm{t} 2=65.5 \mathrm{~s})\end{array}$} & \multirow{7}{*}{$\begin{aligned} \Delta \mathrm{X} & =+1.801 \\
(\mathrm{t} 2 & =69.5 \mathrm{~s}) \\
\Delta \mathrm{Y} & =+1.612 \\
(\mathrm{t} 2 & =65.5 \mathrm{~s})\end{aligned}$} & $\begin{array}{c}\text { RF084 } \\
\Delta=0.84 \mathrm{~m} \\
\phi=45.3\end{array}$ & $\begin{aligned} \Delta \mathrm{X} & =+1.208 \\
(\mathrm{t} 2 & =70.0 \mathrm{~s}) \\
\Delta \mathrm{Y} & =+1.013 \\
(\mathrm{t} 2 & =65.0 \mathrm{~s})\end{aligned}$ \\
\hline $\begin{array}{c}\Delta \mathrm{X}=+0.799 \\
(\mathrm{t} 2=69.0 \mathrm{~s}) \\
\Delta \mathrm{Y}=+0.467 \\
(\mathrm{t} 2=67.0 \mathrm{~s})\end{array}$ & $\begin{array}{c}\mathrm{NF} 152 \\
\Delta=1.52 \mathrm{~m} \\
\phi=48.8\end{array}$ & & & $\begin{array}{c}\text { RF152 } \\
\Delta=1.52 \mathrm{~m} \\
\phi=48.8\end{array}$ & $\begin{aligned} \Delta \mathrm{X} & =+0.799 \\
(\mathrm{t} 2 & =69.0 \mathrm{~s}) \\
\Delta \mathrm{Y} & =+0.467 \\
(\mathrm{t} 2 & =67.0 \mathrm{~s})\end{aligned}$ \\
\hline $\begin{array}{c}\Delta \mathrm{X}=+0.546 \\
(\mathrm{t} 2=62.5 \mathrm{~s}) \\
\Delta \mathrm{Y}=+0.051 \\
(\mathrm{t} 2=68.0 \mathrm{~s})\end{array}$ & $\begin{array}{c}\mathrm{NF} 200 \\
\Delta=2.00 \mathrm{~m} \\
\phi=51.2\end{array}$ & & & $\begin{array}{c}\text { RF200 } \\
\Delta=2.00 \mathrm{~m} \\
\phi=51.2\end{array}$ & $\begin{aligned} \Delta \mathrm{X} & =+0.546 \\
(\mathrm{t} 2 & =62.5 \mathrm{~s}) \\
\Delta \mathrm{Y} & =+0.051 \\
(\mathrm{t} 2 & =68.0 \mathrm{~s})\end{aligned}$ \\
\hline $\begin{array}{c}\Delta \mathrm{X}=-0.115 \\
(\mathrm{t} 2=66.5 \mathrm{~s}) \\
\Delta \mathrm{Y}=-0.127 \\
(\mathrm{t} 2=68.5 \mathrm{~s})\end{array}$ & $\begin{array}{c}\mathrm{NF} 259 \\
\Delta=2.59 \mathrm{~m} \\
\phi=42.2\end{array}$ & & & $\begin{array}{c}\text { RF259 } \\
\Delta=2.59 \mathrm{~m} \\
\phi=42.2\end{array}$ & $\begin{aligned} \Delta \mathrm{X} & =-0.115 \\
(\mathrm{t} 2 & =66.5 \mathrm{~s}) \\
\Delta \mathrm{Y} & =-0.127 \\
(\mathrm{t} 2 & =68.5 \mathrm{~s})\end{aligned}$ \\
\hline $\begin{array}{c}\Delta \mathrm{X}=-0.264 \\
(\mathrm{t} 2=67.0 \mathrm{~s}) \\
\Delta \mathrm{Y}=-0.565 \\
(\mathrm{t} 2=60.0 \mathrm{~s})\end{array}$ & $\begin{array}{c}\mathrm{NF} 300 \\
\Delta=3.00 \mathrm{~m} \\
\phi=46.5\end{array}$ & & & $\begin{array}{c}\text { RF300 } \\
\Delta=3.00 \mathrm{~m} \\
\phi=46.5\end{array}$ & $\begin{aligned} \Delta \mathrm{X} & =-0.264 \\
(\mathrm{t} 2 & =67.0 \mathrm{~s}) \\
\Delta \mathrm{Y} & =-0.565 \\
(\mathrm{t} 2 & =60.0 \mathrm{~s})\end{aligned}$ \\
\hline $\begin{array}{c}\Delta \mathrm{X}=-0.633 \\
(\mathrm{t} 2=68.5 \mathrm{~s}) \\
\Delta \mathrm{Y}=-0.869 \\
(\mathrm{t} 2=62.0 \mathrm{~s})\end{array}$ & $\begin{array}{c}\text { NF348 } \\
\Delta=3.48 \mathrm{~m} \\
\phi=45.5\end{array}$ & & & $\begin{array}{c}\text { RF348 } \\
\Delta=3.48 \mathrm{~m} \\
\phi=45.5\end{array}$ & $\begin{array}{c}\Delta \mathrm{X}=-0.633 \\
(\mathrm{t} 2=68.5 \mathrm{~s}) \\
\Delta \mathrm{Y}=-0.869 \\
(\mathrm{t} 2=62.0 \mathrm{~s})\end{array}$ \\
\hline $\begin{array}{c}\Delta \mathrm{X}=-0.876 \\
(\mathrm{t} 2=68.0 \mathrm{~s}) \\
\Delta \mathrm{Y}=-1.412 \\
(\mathrm{t} 2=63.0 \mathrm{~s})\end{array}$ & $\begin{array}{c}\mathrm{NF} 404 \\
\Delta=4.04 \mathrm{~m} \\
\phi=48.5\end{array}$ & & & $\begin{array}{c}\text { RF404 } \\
\Delta=4.04 \mathrm{~m} \\
\phi=48.5\end{array}$ & $\begin{aligned} \Delta \mathrm{X} & =-0.876 \\
(\mathrm{t} 2 & =68.0 \mathrm{~s}) \\
\Delta \mathrm{Y} & =-1.412 \\
(\mathrm{t} 2 & =63.0 \mathrm{~s})\end{aligned}$ \\
\hline
\end{tabular}

Using these combinations, dynamic analyses considering both inertial force and relative displacement were achieved. Simultaneously, non-linear static analyses corresponding to each residual displacement were carried out.

\section{Analytical Results of Bridge Damage under Normal Fault}

Figure 8 shows the analytical results of the bridge damage under normal fault. In the figure, SNF indicates the result of static analysis, and NF indicates the analytical result considering both fault displacement and inertial force.

In addition to this, the circle in the figure means yielding of the element and the square indicates that the element 
reached ultimate curvature.

Though no ultimate element appears in SNF084cm, bridge damage obtained by NF084cm shows that the ultimate element appeared at the bottom of right pier.

From (S)NF152 to $(\mathrm{S}) \mathrm{NF} 404 \mathrm{~cm}$, both analytical results shows that ultimate element appeared on several points. However, the damage of the bridge under both fault displacement with inertial force was severer than that of under only the case considering fault displacement.

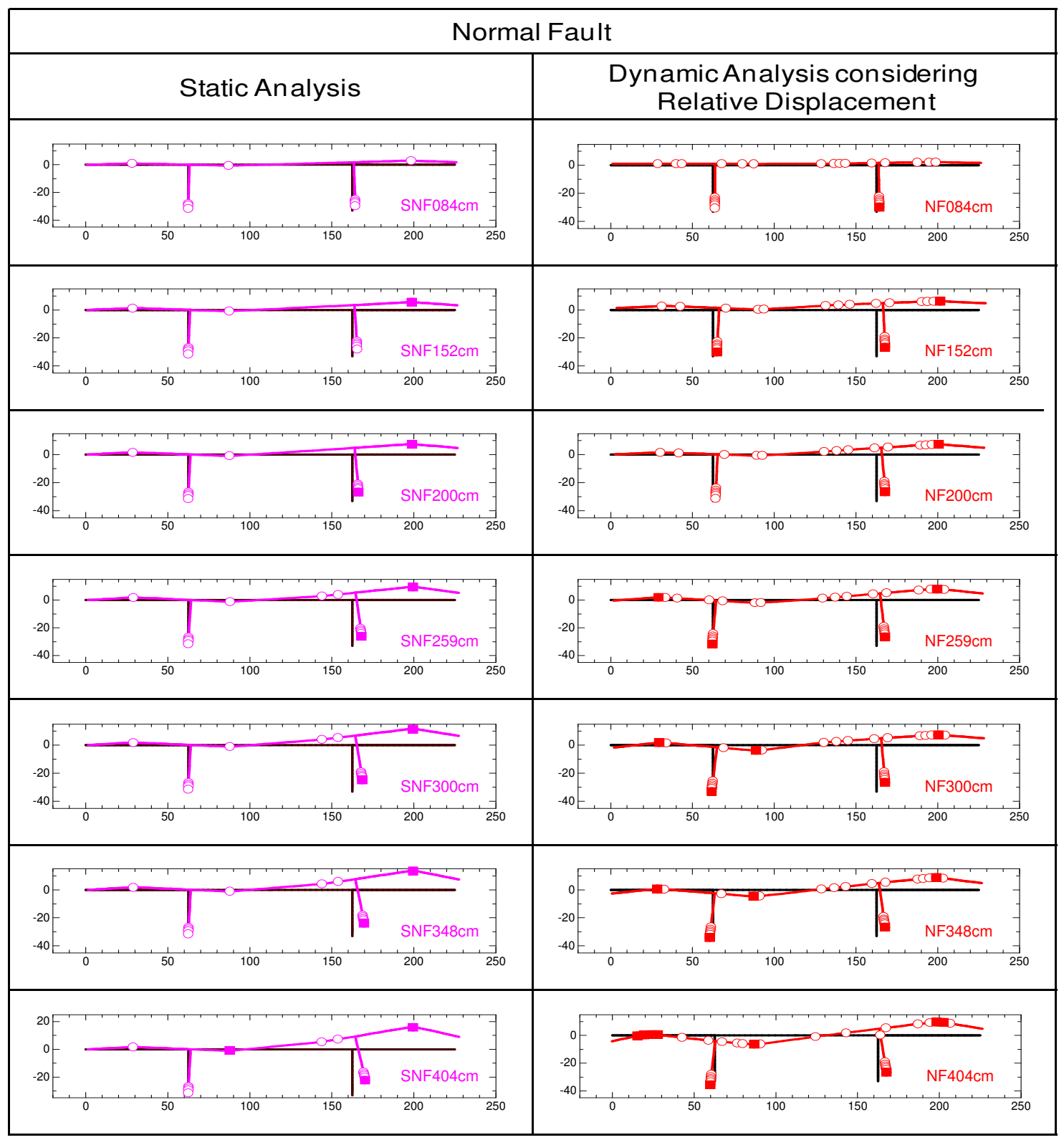

Figure 8: Analytical Results of Bridge Damage under Normal Fault 
Analytical Results of Bridge Damage under Reverse Fault

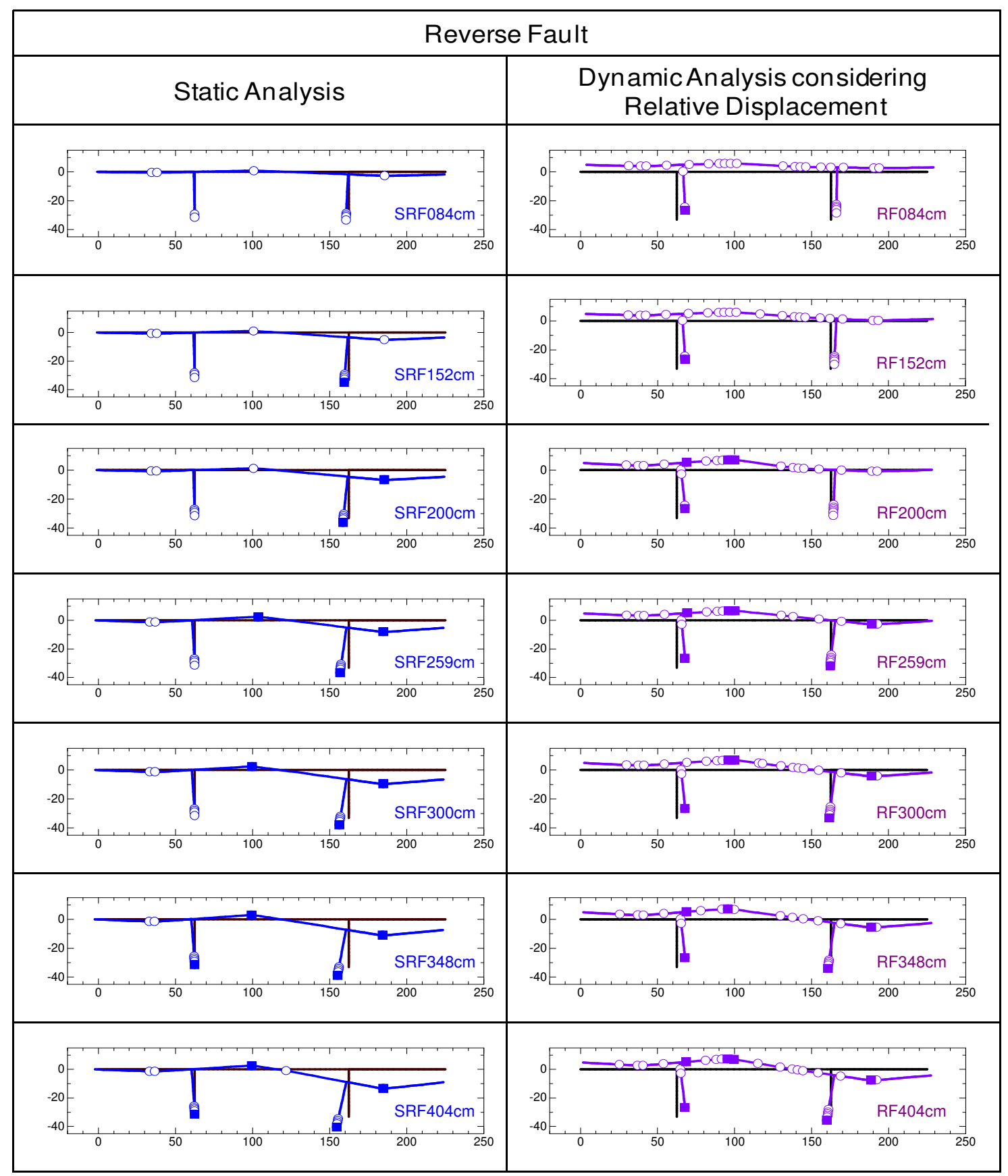

Figure 9: Analytical Result of Bridge Damage under Reverse Fault

Figure 9 shows the analytical result of bridge damage under reverse fault. In the figure, SRF indicates the result of static analysis and RF indicates the analytical result considering both fault displacement and inertial force.

All the tendency of damage distribution is similar to that under normal fault.

It can be seen that, from (S)RF348cm or more relative displacement, the damage distribution resembles each other.

However, the damage distribution of the bridge under both fault displacement with inertial force was severer than that of under only the case considering fault displacement. 


\section{CONCLUSIONS}

Some numerical simulations of a rahmen bridge, under normal and reverse fault movement in several fault displacements were carried out in this study. According to the analytical results, it can be concluded as follows.

- In all the cases, the damage distribution of the bridge under fault displacement with inertial force was severer than that of under only the case considering fault displacement.

- There are some cases that we can predict the damage of bridge under fault movement, considering inertial force using static analysis. However, it depends on the fault movement direction.

- The effect of the inertial force to the bridge damage cannot be evaluated by the conventionally static analysis.

\section{REFERENCES}

1. Nakano, T. and Ohta, Y. (2008), Non-linear Dynamic Response Analysis of Bridge crossing Earthquake Fault Rupture Plane, The 14 ${ }^{\text {th }}$ WCEE, 0502-0127 (DVD Format)

2. Nakano, T., (2014), A Numerical Method for Dynamic Response Analysis of Structure Subjected to Relative Displacement between Support Points, The SIJ Transactions on Computer Networks \& Communication Engineering, Vol.2, No.3, 36-42.

3. Nakano, T., (2014), Analytical Study on Non-linear Dynamic Response of PC Rahmen Bridge under Fault Movement, The $2^{\text {nd }}$ Annual Conference on Civil engineering and Engineering, CD-Format, Phuket, Thailand, March 14-16.

4. Ohta, Y. and Aydan, O. (2007), An Integration Technique for Ground Displacement from Acceleration Records and its Application to Actual Earthquake Records, Journal of the school of Marine Science and Technology, Tokai University, 5(2),112

5. Maekawa, K., and Tsuchiya, S. (2002), Nonlinear Analysis based Verification of Structural Seismic Performance for Practice, Proceedings of fib Congress, Osaka, Japan, Session 6, 1-16a.

6. Taiwan Central Weather Bureau (2016), Taiwan Central Weather Bureau Website, http://www.cwb.gov.tw/V7e/earthquake/chichi.htm

7. Japan Road Association (2002), Specifications for Highway Bridges : Part V Seismic Design, Japan Road Association. 